medRxiv preprint doi: https://doi.org/10.1101/2020.09.30.20204438; this version posted October 2, 2020. The copyright holder for this preprint (which was not certified by peer review) is the author/funder, who has granted medRxiv a license to display the preprint in It is made available under a CC-BY-ND 4.0 International license.

\title{
The genetic architecture of medication-use
}

$6 \quad{ }^{2}$ Centre for Quantitative Genetics and Genomics, Aarhus University, 8830 Tjele, Denmark

$7 \quad 3$ Department of Biomedicine, Aarhus University, 8000 Aarhus, Denmark

$8 \quad{ }^{*}$ Corresponding author: palledr@bio.aau.dk 
medRxiv preprint doi: https://doi.org/10.1101/2020.09.30.20204438; this version posted October 2, 2020. The copyright holder for this

preprint (which was not certified by peer review) is the author/funder, who has granted medRxiv a license to display the preprint in perpetuity.

It is made available under a CC-BY-ND 4.0 International license .

\section{Abstract}

Genomics has been forecasted to revolutionise human health by improving medical treatment through a better understanding of the molecular mechanisms of human diseases. Despite great successes of the last decade's genome-wide association studies (GWAS), the results have to a limited extent been translated to genomic medicine. We propose, that one route to get closer to improved medical treatment is by understanding the genetics of medication-use. Here we obtained entire medication profiles from 335,744 individuals from the UK Biobank and performed a GWAS to identify which common genetic variants are major drivers of medication-use. We analysed 9 million imputed genetic variants, estimated SNP heritability, partitioned the genomic variance across functional categories, and constructed genetic scores for medication-use. In total, 59 independent loci were identified for medication-use and approximately $18 \%$ of the total variation was attributable to common genetic (minor allele frequency $>0.01$ ) variants. The largest fraction of variance was captured by variants with low to medium minor allele frequency. In particular coding and conserved regions, as well as transcription start sites, displayed significantly enrichment of heritability. The average correlation between medication-use and predicted genetic scores was 0.14 . These results demonstrate that medication-use per se is a highly polygenic complex trait and that individuals with higher genetic liability are on average more diseased and have a higher risk for adverse drug reactions. These results provide an insight into the genetic architecture of medication use and pave the way for developments of multicomponent genetic risk models that includes the genetically informed medication-use. 
medRxiv preprint doi: https://doi.org/10.1101/2020.09.30.20204438; this version posted October 2, 2020. The copyright holder for this

preprint (which was not certified by peer review) is the author/funder, who has granted medRxiv a license to display the preprint in

It is made available under a CC-BY-ND 4.0 International license .

\section{Introduction}

Understanding the relationship between DNA sequence variation and the predisposition to common diseases has interested researchers for decades. In particular after the initial release of the human genome (1), the number of polymorphic genetic variants associated with disease predisposition has grown exponentially to more than 60,000 associations (2-4). Genome-wide association studies (GWAS) have provided new insight into the biology and genetic epidemiology of many human complex diseases, which is essential for innovative developments within genomic medicine.

The traditional one-size-fits-all approach for disease diagnosis and treatment has been proven to be inefficient, expensive and sometimes with adverse clinical reactions. Personalised medicine or genomic medicine, which often are used interchangeably (5), is foreseen to change the way we prevent, diagnose and treat medical conditions $(6,7)$. The goal of genomic medicine is to develop targeted preventive or treatment approaches based on the individual's genetic makeup, environmental exposures and lifestyle parameters (6,7). Fundamental for development of genomic medicine is accurate knowledge about the disease pathogenesis. Equally important is the realisation of the genetic contributions to drug response per se (8-10). Genetic variation among patients modulates the drug efficiency and can impose toxic effects (adverse drug reactions) $(11,12)$. Therefore, understanding the genetic architecture of drug response is absolutely essential for the development of genomic medicine.

A major challenge and hindrance in studying genetic factors influencing drug response variability is the lack of accessible data. Despite the emerge of large biobanks such as the United Kingdom Biobank (13), Japan Biobank (14) and Estonia Biobank (15), that contain genetic and deep phenotypic information of the participants, information on response to medical treatment is absent. The accessibility of electronic health records and selfreported health status may provide means for alternative approaches for studying the genetic basis of traits of relevance for medication-use.

Previously, Wu et al. (2019)(16) performed a genetic analysis of medication-use in the United Kingdom Biobank (UKBB). They categorised medications based on the drugs active substances according to the organ or system they act on and their pharmacological properties. They performed a genetic analysis on 23 isolated groups of medications and identified a very large number of independent loci associated with the different drug categories. Instead of grouping drugs based on the active substances and analysing those individually, we investigated the entire medication profile of individuals from the UKBB. The aim of the current study was to investigate the genetic basis of self-reported medication-use in the UKBB. We defined medication-use as the total number of different prescription and over-the-counter medications individuals were taking at the time of the verbal interview with the 
medRxiv preprint doi: https://doi.org/10.1101/2020.09.30.20204438; this version posted October 2, 2020. The copyright holder for this preprint (which was not certified by peer review) is the author/funder, who has granted medRxiv a license to display the preprint in perpetuity.

It is made available under a CC-BY-ND 4.0 International license.

UKBB assessment centres. Medication-use - as defined above - has the clear advantage that it is easily quantifiable compared to for example drug efficiency. Assuming current medication-use as a quantitative trait phenotype we conducted a genetic analysis of 335,744 unrelated individuals from the UKBB. We hypothesised that across medical conditions, medication-use has a detectable genetic component, and expected medication-use to be genetically correlated with common diseases as commonly prescribed drugs is likely to be a proxy for major disease groups. Extensive medication-use has in individuals older than 65 years been shown to be associated with ill health and morbidity $(17,18)$; hence, we further hypothesised that medication-use was genetically correlated with healthrelated outcomes. If medication-use has a genetic component, understanding the genetic basis is important because many medications has side effects, and increased drug usage might be associated with higher risk of toxic effects. Hence, genetic predisposition to high medication-use could be used as guidance in treatment plans aiming to reduce the total number of medications.

\section{Results}

We performed a genetic analysis of current medication-use within the white British cohort of the UK Biobank $(n=335,744)$. We defined current medication-use as the number of different prescription and over-the-counter medicines the participants were taking regularly at the time of the verbal interview (short term medication, like antibiotics or analgesics was not included). The average number of medications taken by males were 2.34 (standard deviation (sd) 2.7) and 2.67 (sd 2.7) for females, with a linear increase in the number of medications taken with increasing age (Supplementary Figure S1). Interestingly, the mean number of drugs taken for individuals with an ICD10-code for adverse drug reaction (Supplementary Table S1)(19) was significant larger (mean=4.09, sd=3.57) than individuals without such diagnoses (mean=2.23, sd=2.43; $\mathrm{t}$-test=-101.77, $\mathrm{df}=46662, P<2.2 \times 10^{-16}$ ), suggesting that individuals taking a larger number of mediations are more likely to encounter an adverse drug reaction or that individuals experiencing adverse drug reactions are harder to treat, requiring more medication. . The participants have reported a total of 3,247 different medications, where the most frequently used drugs were paracetamol $(n=61,604)$, aspirin $(n=44,894)$, ibuprofen $(n=41,756)$ and simvastatin $(n=38,379)$ (Supplementary Table S2).

After SNP quality control (see Methods) there were 9,804,629 autosomal SNPs left for GWAS analysis. In total, we identified 59 independent quantitative trait loci for current medication-use (Fig. 1, Supplementary Table S3). The strongest associated locus was within the human leucocyte antigens (HLA) complex (rs35248896, $P=1.52 \times 10^{-}$ 46). Because of the complexity of the HLA region $(20,21)$ we only allowed one significant locus at this genomic region 
medRxiv preprint doi: https://doi.org/10.1101/2020.09.30.20204438; this version posted October 2, 2020. The copyright holder for this preprint (which was not certified by peer review) is the author/funder, who has granted medRxiv a license to display the preprint in perpetuity.

It is made available under a CC-BY-ND 4.0 International license .

(additional three loci passed the significance threshold within the HLA region but were excluded, Supplementary Table S3). Among the 59 genome-wide significant loci 14 of them were located in intergenic regions.

Using the medication-use GWAS summary statistics (excluding the HLA region) we estimated the proportion of variation in medication-use explained by the SNPs $\left(h_{S N P}^{2}\right)$ to $0.18 \pm 0.005$. Next, we partitioned the total heritability to heritability captured by individual autosomal chromosomes and found a linear association between the proportion of heritability captured by each autosomal chromosome and the number of SNPs per chromosome $\left(\mathrm{R}^{2}=0.9\right.$, Fig. $\left.2 \mathrm{~A}\right)$ suggesting that medication-use is a highly polygenic trait. The genomic variance explained per variant within minor allele frequency bins indicate that low frequent variants capture about 3 times more genetic variance than higher frequent variants does (Fig. 2B). Also, we estimated the enrichment score across 24 functional categories (obtained from Finucane et al (2015) (22)), which is the estimated share of $h_{S N P}^{2}$ divided by its expected share under the assumed heritability model $(22,23)$ (Fig 2C). In particular, the conserved genomic region and transcription start sites (TSS) were highly enriched accounting for $4.5 \%$ and $1.3 \%$ of $h_{S N P}^{2}$, respectively.

We constructed genetic scores for medication-use by re-estimating the SNP-effects using a five-fold cross validation scheme. The scoring was performed on five levels of LD pruning $\left(\mathrm{r}^{2}\right)$ and across eleven $P$-value thresholds. The maximum prediction accuracy (correlation between genetic scores and medication-use $\sim 0.14$ ) was obtained when removing markers with $\mathrm{r}^{2}>0.5$ (Supplementary Fig. S2) at a $P$-value of 0.9 (Fig. 3A), which includes about 1.5 million genetic markers (Supplementary Fig. S3). Stratifying individuals based on their genetic score we see that individuals within the top 5\% highest genetic score has increased medication-use compared with individuals with the 5\% lowest genetic score (Fig. 3B, Supplementary Fig. S4). Moreover, individuals with the 5\% highest genetic scores has significant more ICD10 diagnoses than those individuals with the 5\% lowest genetic scores (10.8 diagnoses and 6.4 diagnoses, respectively, Supplementary Fig. S5). There is, however, no visual difference in which diseases they have been diagnosed with (Supplementary Fig. S6); individuals with the highest genetic score for medication-use simply has more diagnoses than those with low genetic scores (Supplementary Fig. S5B and Fig. S6). Using the classification of adverse drug reactions from Hohl et al. (2014) (19) (Supplementary Table S1), we further see, that individuals with predicted high risk and an experience of adverse drug reactions on average have a 1.6 fold higher medication-use compared with low risk individuals (Supplementary Fig. S7 and Table S5).

Finally, we computed the genetic correlation between medication-use and 257 quantitative traits and complex diseases using LD Hub (24). We found a significant genetic correlation with 115 traits (Bonferroni adjusted $P$ value $<0.01$ ) across 26 categories, except bone traits, where no genetic correlation with medication use was found (Fig. 4, Supplementary Table S4). Expectedly, medication-use was positively genetically correlated with major common 
medRxiv preprint doi: https://doi.org/10.1101/2020.09.30.20204438; this version posted October 2, 2020. The copyright holder for this preprint (which was not certified by peer review) is the author/funder, who has granted medRxiv a license to display the preprint in perpetuity.

It is made available under a CC-BY-ND 4.0 International license.

complex diseases in particularly coronary artery disease, type 2 diabetes, asthma, lung cancer and major depressive disorder (Fig. 5). Parents age at death was the trait that was most negatively genetically correlated with medicationuse indicating that higher medication use correlate with lower age at death (higher mortality) of parents (Fig. 5). We also found that the number of years in school and if completed college were negatively correlated with medication-use. Number of cigarettes smoked per day and medication-use was positively genetically correlated, and medication-use was also genetically correlated with sleep traits; insomnia and sleep duration (Fig. 5). Finally, we estimated genetic correlations between medication-use and the medication categories previously published by Wu et al. (2019) (16) (Supplementary Figure S8). The average genetic correlation between our definition of medication-use and the 23 medication categories was 0.52 (sd 0.22; Supplementary Table S6), and the category 'drugs affecting bone structure and mineralization' was the only insignificant result, which is in agreement with the observation that medication-use was not genetically correlated with any bone traits (Fig. 4).

\section{Discussion}

In this study, we used data from the UK Biobank to perform a genetic analysis of current medication-use, defined as the total number of different prescription and over-the-counter drugs UKBB participants were taking at the time of the initial assessment. Our aim was to investigate the genetic basis of self-reported medication-use. We identified 59 linkage disequilibrium independent SNPs $\left(P<5 \cdot 10^{-8}\right)$ associated with current medication-use (Fig. 1). The strongest signal was located within the major histocompatibility complex (MHC); HLA-DQA1 (lead SNP rs35248896, $P$ value $=1.52 \cdot 10^{-46}$ ), which belongs to the MHC class II gene. The MHC region is a large genomic region on chromosome 6 that is associated with more diseases than any other region of the genome $(20,25)$. Additional three loci within MCH reached LD-independently genome-wide significance (Supplementary Table S3), however, the complexity and extreme variant polymorphism, combined with strong LD, within MHC complicates interpretation and disentanglement of individual loci (26). Given the biological involvement of MHC in immune response, it was unsurprisingly that exactly this region was the strongest associated loci.

The associated loci have previously been linked to a large number of different quantitative traits and complex diseases. Since the genetic correlations express the extent to which two measurements reflect what is genetically the same character (27), it is not too surprisingly that we see a good correspondence between the identified loci (Fig. 1) and their previous associations and the significant genetic correlations (Fig. 5, Supplementary Table S4). For example, among our candidate genes (Supplementary Table S3) we have susceptibility loci for diabetes (PTPN22, CEP68, RREB1, TCF7L2 (28-30)), coronary artery disease (PSRC1, UNC5C , LPLA (31)), depression 
medRxiv preprint doi: https://doi.org/10.1101/2020.09.30.20204438; this version posted October 2, 2020. The copyright holder for this

preprint (which was not certified by peer review) is the author/funder, who has granted medRxiv a license to display the preprint in perpetuity.

It is made available under a CC-BY-ND 4.0 International license .

(MAD1L1, YLPM1 (32,33)), and insomnia (NMT1 (34)). But also for non-disease traits including BMI (RABGAP1L, HEYL $(35,36)$ ), smoking (NLGN1 (37)), and age at menarche (RBM6 (38)).

The polygenic nature of medication-use was, aside from the large number of identified quantitative trait loci, further supported by the linear association between proportion of genetic variance captured by each autosomal chromosome and the proportion of genetic variants (Fig. 2A), which is similar to what is seen for other complex, polygenic traits (39-43). We observed that low frequent alleles capture more genetic variance than common variants (Fig. 2B), which is similar to what is seen in for example type 2 diabetes (44) and coronary artery disease $(42,45)$. Neurodevelopmental and -degenerative disorders, like schizophrenia, Tourette syndrome and Alzheimer disease, do, however, show the opposite pattern $(39,40,46)$. Therefore, it is not surprisingly that our findings correspond with what is seen for common diseases since the disease prevalence of common diseases in the UKBB follows the population prevalence, and further that the prevalence of mental disorders is too low compared to the population frequency.

Our statistical genetic analysis was performed across any medical condition the included UKBB participants may be diagnosed with as our interest was to study the genetic contributions to variation in medication-use. Thus, our findings could be biased towards the common diseases with the highest disease prevalence, for example through partially shared genetic aetiology. However, this would inevitable imply that some disease groups require numerically more drugs for treatment than other disease groups. Our results clearly demonstrated that individuals with high genetic score for medication-use had an increased medication usage (Fig. 3B), and that this was associated with higher probability of have more disease diagnoses (Supplementary Fig. S5) and having experienced an adverse drug reaction (Supplementary Fig. S7). Thus, it appears, that the individuals with large medication-use has a genetic predisposition towards increased medication demand likely because of poor health from being predisposed to a larger number of different diseases, leading to increased risk of responding negatively to the prescribed medical treatment. Supportive for this, is that we see medication-use to be genetically correlated with known indicators of poor health (Fig. 5). We found, for example, overweight and high body mass index, known to be under strong genetic influence (47), to be positively correlated with medication-use, and these are strongly associated with poor health (48-50). Moreover, the behavioural characteristics smoking and sleep patterns, are also known factors for bad state of health $(51,52)$, which also displayed significant genetic correlations with medication-use (Fig. 5).

This study has a number of limitations. First, despite the information on medication-use was obtained by trained nurses during interviews, the same drug may have been reported under different names, which may limit the accuracy of the analysis. Second, our definition of drug usage also includes vitamins. However, for many 
medRxiv preprint doi: https://doi.org/10.1101/2020.09.30.20204438; this version posted October 2, 2020. The copyright holder for this preprint (which was not certified by peer review) is the author/funder, who has granted medRxiv a license to display the preprint in perpetuity.

It is made available under a CC-BY-ND 4.0 International license .

diseases, dietary supplements are used in the pharmacological intervention, thus, to prune out vitamins might not more accurately capture the individual's medication profile. Third, the lack of information on medication duration, dosage and response entails that true pharmacogenomic analysis cannot be performed. Fourth, the self-reported nature of the phenotype may limit the precision; however, studies have shown good concordance between selfreported and electronic health records, both for diseases (53) and for medication-use (54). Fifth, the findings presented here are specific to the UK Biobank participants, which is not representative of the general UK population $(55,56)$, and may not translate to other populations and other health systems.

In conclusion, we have shown that the genetic basis of current medication-use in the UK Biobank among 335,744 individuals appears genetically heterogeneous. We identified 59 independent quantitative trait loci for medication-use and found that $18 \%$ of the observed variation could be ascribed to common genetic variants. The genetic heterogenous nature of medication-use was further supported as the genetic variance was spread across the genome, and that the highest accuracy of prediction was observed when including 1.5 million genetic markers. Our findings that medication-use was strongly correlated with smoking behaviour, parents age of death, educational level and insomnia, suggest that the genetic architecture is not biased towards common diseases. Understanding the genetic aetiology of complex diseases has been suggested as a route for improving medical treatment $(57,58)$. Medication-use - as defined in the current study - is an easy quantifiable trait, and because of its genetically corelated nature with many complex traits and diseases, incorporating such information into new multicomponent genetic risk scores (59) could further increase the accuracy of predicting disease predispositions and disease trajectories. From genetic data we can identify those individuals with high medication-use, which concurrently are the most diseased individuals, and they are at an increased risk for adverse drug reaction. Thus, individual medication profiles are likely to be yet another puzzle piece in understanding complex for human diseases, and for providing better medical treatment for future generation.

\section{Material and Methods}

\section{Genotype and phenotype data}

Genetic and phenotypic data were obtained from the United Kingdom Biobank (UKB) $(13,60)$. Data has been collected for more than 500.000 individuals aged 37-73 years. Genotyping details has been described previously (13). To obtain a genetic homogeneous study population we restricted our analyses to unrelated Caucasians, and excluded individuals with more than 5,000 missing genotypes or individuals with autosomal aneuploidy $(n=335.744)$. We first converted the imputed genotype probabilities to hard-call genotypes using PLINK2 (--hard- 
medRxiv preprint doi: https://doi.org/10.1101/2020.09.30.20204438; this version posted October 2, 2020. The copyright holder for this

preprint (which was not certified by peer review) is the author/funder, who has granted medRxiv a license to display the preprint in perpetuity.

It is made available under a CC-BY-ND 4.0 International license .

call 0.1) (61), and variants with MAF $<0.01$, missing genotype rate $>0.05$, Hardy-Weinberg equilibrium test $P$ value $<1 \times 10^{-6}$, or imputation info score $<0.3$ were excluded $(m=9.804 .629)$.

We defined current medication-use as the number of different prescription and over-the-counter medicines (Data Field: 20003) the participants were taking regularly at the time of the verbal interview. Any short-term medications, like antibiotics or analgesics were not registered at the interview. From Hohl et al. (2013)(19) we obtained a list of ICD10 codes commonly used to describe adverse drug reactions (Supplementary Table S1).

\section{Genome-wide association study (GWAS) of medication-use}

Using PLINK2 (61) we performed a GWAS on medication-use for the entire White-British cohort with sex, age, UKB assessment centre, and the first ten genetic principal components as covariates. To identify high confidence independent associated loci, we performed LD-based clumping in window size of $1000 \mathrm{~kb}$ with $\mathrm{r}^{2}<0.01$, and for the major histocompatibility complex region we only allowed one significant locus. Lead SNPs within each independent genome-wide significant locus was annotated to nearest gene (genome build GRCh37, hg19) within $2000 \mathrm{~kb}$ using Variant Effect Predictor (62).

\section{Estimation of heritability and genetic correlations}

We estimated the proportion of variation in medication-use explained by SNPs $\left(h_{S N P}^{2}\right)$ using SumHer (23). We excluded variants within the HLA region (as suggested by the authors of SumHer), and the estimation was performed assuming the LDAK heritability model. In addition, we estimated enrichment for 24 functional categories (obtained from Finucane et al. (2015)(22)), and further partitioned $h_{S N P}^{2}$ to autosomal chromosomes and minor allele frequency bins.

As it has been shown that SumHer and LD Score regression (63) has similar accuracy in estimation of genetic correlations (23), we used LD Hub to estimate the genetic correlations between medication-use (excluding the HLA region) and 257 quantitative and disease traits (24). To account for multiple testing, we adjusted all $P$-values using Bonferroni $\left(P_{a d j}<0.01\right)$. Using LD Score regression (63) we also computed the genetic correlation between our definition of medication-use and the previously published genetic analysis of categories of medication traits (16). The univariate LD scores were computed using the 1000 Genomes European data.

\section{Constructing genetic scores for medication-use}

To construct within-cohort genetic scores we reran the GWAS in PLINK2 on five subdivision of the White-British cohort (i.e., a five-fold cross validation scheme). For each set of summary statistics we performed LD clumping (for 
medRxiv preprint doi: https://doi.org/10.1101/2020.09.30.20204438; this version posted October 2, 2020. The copyright holder for this

preprint (which was not certified by peer review) is the author/funder, who has granted medRxiv a license to display the preprint in

It is made available under a CC-BY-ND 4.0 International license .

$\left.r^{2}<\{0.1,0.3,0.5,0.7,0.9\}\right)$ implemented in the R package qgg (41) using a range of $P$ value thresholds $(0.001,0.01$, $0.05,0.1,0.2,0.3,0.4,0.5,0.7,0.9,0.999)$, and computed the genetic scores as $G S=\sum_{i=1}^{m} \boldsymbol{w}_{i} \hat{\boldsymbol{s}}_{i}$, where $\boldsymbol{w}_{i}$ is the $i$-th genotype (allelic counts), $\hat{\boldsymbol{s}}_{i}$ is the estimated SNP effect, and $m$ is the number of SNPs left after LD pruning and $P$ value thresholding.

The accuracy of the genetic scores were obtained as the correlation between the number of medications taken of the individuals in the training set and the predicted genetic score. The genetic scores were divided into percentiles, and regression coefficients $(\beta)$ were estimated by linear regression of the number of medications taken on the genetic score percentile relative to the $50^{\text {th }}$ genetic score percentile, adjusted for sex, age, UKB assessment centre, and the first ten genetic principal components.

\title{
Conflict of interest statement
}

The authors declare no competing interests.

\section{Funding}

This work was supported by a Lundbeck Foundation grant to PDR (R287-2018-735).

\begin{abstract}
Abbreviations
GWAS, genome-wide association study; ICD10, International Classification of Diseases, version10; SNP, single nucleotide polymorphisms; UKBB, United Kingdom Biobank
\end{abstract}

\section{Acknowledgements}

All of the computing for this project was performed on the GenomeDK cluster. We would like to thank GenomeDK and Aarhus University for providing computational resources and support that contributed to these research results. The genetic and phenotypic data were obtained from the UK Biobank Resource (ID 31269). 
medRxiv preprint doi: https://doi.org/10.1101/2020.09.30.20204438; this version posted October 2, 2020. The copyright holder for this preprint (which was not certified by peer review) is the author/funder, who has granted medRxiv a license to display the preprint in It is made available under a CC-BY-ND 4.0 International license.

\section{References}

1. Lander, E. S., Linton, L. M., Birren, B., et al. (2001) Initial sequencing and analysis of the human genome. Nature, 409, 860-921.

2. Buniello, A., Macarthur, J. A. L., Cerezo, M., et al. (2019) The NHGRI-EBI GWAS Catalog of published genome-wide association studies, targeted arrays and summary statistics 2019. Nucleic Acids Res., 47, D1005-D1012.

3. Claussnitzer, M., Cho, J. H., Collins, R., et al. (2020) A brief history of human disease genetics. Nature, 577, 179189.

4. Visscher, P. M., Wray, N. R., Zhang, Q., et al. (2017) 10 Years of GWAS Discovery: Biology, Function, and Translation. Am. J. Hum. Genet., 101, 5-22.

5. Ciardiello, F., Arnold, D., Casali, P. G., et al. (2014) Delivering precision medicine in oncology today and in futurethe promise and challenges of personalised cancer medicine: A position paper by the European Society for Medical Oncology (ESMO). Ann. Oncol., 25, 1673-1678.

6. Ginsburg, G. S. and McCarthy, J. J. (2001) Personalized medicine: Revolutionizing drug discovery and patient care. Trends Biotechnol., 19, 491-496.

7. Ashley, E. A. (2016) Towards precision medicine. Nat. Rev. Genet., 17, 507-522.

8. Schork, N. J. (2015) Personalized medicine: Time for one-person trials. Nature, 520, 609-611.

9. Schärfe, C. P. I., Tremmel, R., Schwab, M., et al. (2017) Genetic variation in human drug-related genes. Genome Med., 9, 1-15.

10. Madian, A. G., Wheeler, H. E., Jones, R. B., et al. (2012) Relating human genetic variation to variation in drug responses. Trends Genet., 28, 487-495.

11. Pirmohamed, M. and Park, B. K. (2001) Genetic susceptibility to adverse drug reactions. Trends Pharmacol. Sci., 22, 298-305.

12. Roden, D. M., Wilke, R. A., Kroemer, H. K., et al. (2011) Pharmacogenomics: The genetics of variable drug responses. Circulation, 123, 1661-1670.

13. Bycroft, C., Elliott, L. T., Young, A., et al. (2018) The UK Biobank resource with deep phenotyping and genomic data. Nature, 562, 203-209.

14. Nagai, A., Hirata, M., Kamatani, Y., et al. (2017) Overview of the BioBank Japan Project: Study design and profile. J. Epidemiol., 27, S2-S8.

15. Leitsalu, L., Haller, T., Esko, T., et al. (2015) Cohort profile: Estonian biobank of the Estonian genome center, university of Tartu. Int. J. Epidemiol., 44, 1137-1147.

16. Wu, Y., Byrne, E. M., Zheng, Z., et al. (2019) Genome-wide association study of medication-use and associated disease in the UK Biobank. Nat. Commun., 10, 1-10. 
medRxiv preprint doi: https://doi.org/10.1101/2020.09.30.20204438; this version posted October 2, 2020. The copyright holder for this preprint (which was not certified by peer review) is the author/funder, who has granted medRxiv a license to display the preprint in perpetuity.

It is made available under a CC-BY-ND 4.0 International license.

17. Patel, R. B. (2003) Polypharmacy and the Elderly. J. Infus. Nurs., 26, 166-169.

18. Ramage-Morin, P. L. (2009) Medication use among senior Canadians. Heal. Reports, Stat. Canada, 20, 37-44.

19. Hohl, C. M., Karpov, A., Reddekopp, L., et al. (2014) ICD-10 codes used to identify adverse drug events in administrative data: A systematic review. J. Am. Med. Informatics Assoc., 21, 547-557.

20. Kennedy, A. E., Ozbek, U. and Dorak, M. T. (2017) What has GWAS done for HLA and disease associations? Int. J. Immunogenet., 44, 195-211.

21. Altshuler, D. L., Durbin, R. M., Abecasis, G. R., et al. (2010) A map of human genome variation from populationscale sequencing. Nature, 467, 1061-1073.

22. Finucane, H. K., Bulik-Sullivan, B., Gusev, A., et al. (2015) Partitioning heritability by functional annotation using genome-wide association summary statistics. Nat. Genet., 47, 1228-1235.

23. Speed, D. and Balding, D. J. (2019) SumHer better estimates the SNP heritability of complex traits from summary statistics. Nat. Genet., 51, 277-284.

24. Zheng, J., Erzurumluoglu, A. M., Elsworth, B. L., et al. (2017) LD Hub: A centralized database and web interface to perform LD score regression that maximizes the potential of summary level GWAS data for SNP heritability and genetic correlation analysis. Bioinformatics, 33, 272-279.

25. Dendrou, C. A., Petersen, J., Rossjohn, J., et al. (2018) HLA variation and disease. Nat. Rev. Immunol., 18, 325-339.

26. Trowsdale, J. and Knight, J. C. (2013) Major histocompatibility complex genomics and human disease. Annu. Rev. Genomics Hum. Genet., 14, 301-323.

27. Falconer, D. S. and Mackay, T. F. C. (1996) Introduction to Quantitative Genetics. Introduction to Quantitative Genetics; Fourth edi.; Pearson, (1996) .

28. Todd, J. A., Walker, N. M., Cooper, J. D., et al. (2007) Robust associations of four new chromosome regions from genome-wide analyses of type 1 diabetes. Nat. Genet., 39, 857-864.

29. Mahajan, A., Go, M. J., Zhang, W., et al. (2014) Genome-wide trans-ancestry meta-analysis provides insight into the genetic architecture of type 2 diabetes susceptibility. Nat. Genet., 46, 234-244.

30. Mahajan, A., Taliun, D., Thurner, M., et al. (2018) Fine-mapping type 2 diabetes loci to single-variant resolution using high-density imputation and islet-specific epigenome maps. Nat. Genet., 50, 1505-1513.

31. Van Der Harst, P. and Verweij, N. (2018) Identification of 64 novel genetic loci provides an expanded view on the genetic architecture of coronary artery disease. Circ. Res., 122, 433-443.

32. Howard, D. M., Adams, M. J., Clarke, T. K., et al. (2019) Genome-wide meta-analysis of depression identifies 102 independent variants and highlights the importance of the prefrontal brain regions. Nat. Neurosci., 22, 343-352.

33. Nagel, M., Jansen, P. R., Stringer, S., et al. (2018) Meta-analysis of genome-wide association studies for neuroticism in 449,484 individuals identifies novel genetic loci and pathways. Nat. Genet, 50, 920-927. 
medRxiv preprint doi: https://doi.org/10.1101/2020.09.30.20204438; this version posted October 2, 2020. The copyright holder for this preprint (which was not certified by peer review) is the author/funder, who has granted medRxiv a license to display the preprint in It is made available under a CC-BY-ND 4.0 International license.

34. Jansen, P. R., Watanabe, K., Stringer, S., et al. (2019) Genome-wide analysis of insomnia in 1,331,010 individuals identifies new risk loci and functional pathways. Nat. Genet., 51, 394-403.

35. Kichaev, G., Bhatia, G., Loh, P. R., et al. (2019) Leveraging Polygenic Functional Enrichment to Improve GWAS Power. Am. J. Hum. Genet., 104, 65-75.

36. Zhu, Z., Guo, Y., Shi, H., et al. (2020) Shared genetic and experimental links between obesity-related traits and asthma subtypes in UK Biobank. J. Allergy Clin. Immunol., 145, 537-549.

37. Liu, M., Jiang, Y., Wedow, R., et al. (2019) Association studies of up to 1.2 million individuals yield new insights into the genetic etiology of tobacco and alcohol use. Nat. Genet., 51, 237-244.

38. Perry, J. R. B., Day, F., Elks, C. E., et al. (2014) Parent-of-origin-specific allelic associations among 106 genomic loci for age at menarche. Nature, 514, 92-97.

39. Lee, S. H., Decandia, T. R., Ripke, S., et al. (2012) Estimating the proportion of variation in susceptibility to schizophrenia captured by common SNPs. Nat. Genet., 44, 247-250.

40. Davis, L. K., Yu, D., Keenan, C. L., et al. (2013) Partitioning the Heritability of Tourette Syndrome and Obsessive Compulsive Disorder Reveals Differences in Genetic Architecture. PLoS Genet., 9.

41. Rohde, P. D., Fourie Sørensen, I. and Sørensen, P. (2020) qgg: an R package for large-scale quantitative genetic analyses. Bioinformatics, 36, 2614-2615.

42. Nikpay, M., Stewart, A. F. R., McPherson, R., et al. (2017) Partitioning the heritability of coronary artery disease highlights the importance of immune-mediated processes and epigenetic sites associated with transcriptional activity. Cardiovasc. Res., 113, 973-983.

43. Yang, J., Manolio, T. A., Pasquale, L. R., et al. (2011) Genome partitioning of genetic variation for complex traits using common SNPs. Nat. Genet., 43, 519-525.

44. Xue, A., Wu, Y., Zhu, Z., et al. (2018) Genome-wide association analyses identify 143 risk variants and putative regulatory mechanisms for type 2 diabetes. Nat. Commun., 9.

45. Nikpay, M., Turner, A. W. and McPherson, R. (2018) Partitioning the Pleiotropy Between Coronary Artery Disease and Body Mass Index Reveals the Importance of Low Frequency Variants and Central Nervous SystemSpecific Functional Elements. Circ. Genomic Precis. Med., 11, e002050.

46. Lee, S. H., Harold, D., Nyholt, D. R., et al. (2013) Estimation and partitioning of polygenic variation captured by common snps for alzheimer's disease, multiple sclerosis and endometriosis. Hum. Mol. Genet., 22, 832-841.

47. Locke, A. E., Kahali, B., Berndt, S. I., et al. (2015) Genetic studies of body mass index yield new insights for obesity biology. Nature, 518, 197-206.

48. Al-Goblan, A. S., Al-Alfi, M. A. and Khan, M. Z. (2014) Mechanism linking diabetes mellitus and obesity. Diabetes, Metab. Syndr. Obes. Targets Ther., 7, 587-591. 
medRxiv preprint doi: https://doi.org/10.1101/2020.09.30.20204438; this version posted October 2, 2020. The copyright holder for this preprint (which was not certified by peer review) is the author/funder, who has granted medRxiv a license to display the preprint in It is made available under a CC-BY-ND 4.0 International license.

49. Hruby, A., Manson, J. A. E., Qi, L., et al. (2016) Determinants and consequences of obesity. Am. J. Public Health, 106, 1656-1662.

50. U.S. Department of Health and Human Services (2013) Managing Overweight and Obesity in Adults: Systematic Evidence Review from the Obesity Expert Panel. Managing Overweight and Obesity in Adults: Systematic Evidence Review from the Obesity Expert Panel; (2013) .

51. Paruthi, S., Brooks, L. J., D’Ambrosio, C., et al. (2016) Consensus Statement of the American Academy of Sleep Medicine on the Recommended Amount of Sleep for Healthy Children: Methodology and Discussion. J. Clin. Sleep Med., 12, 1549-1561.

52. (2004) The 2004 United States Surgeon General's Report: The Health Consequences of Smoking. N. S. W. Public Health Bull., 15, 107.

53. DeBoever, C., Tanigawa, Y., Aguirre, M., et al. (2020) Assessing Digital Phenotyping to Enhance Genetic Studies of Human Diseases. Am. J. Hum. Genet.

54. Hafferty, J. D., Campbell, A. I., Navrady, L. B., et al. (2018) Self-reported medication use validated through record linkage to national prescribing data. J. Clin. Epidemiol., 94, 132-142.

55. Fry, A., Littlejohns, T. J., Sudlow, C., et al. (2017) Comparison of Sociodemographic and Health-Related Characteristics of UK Biobank Participants with Those of the General Population. Am. J. Epidemiol., 186, 10261034.

56. Keyes, K. M. and Westreich, D. (2019) UK Biobank, big data, and the consequences of non-representativeness. Lancet, 393, 1297.

57. Plenge, R. M., Scolnick, E. M. and Altshuler, D. (2013) Validating therapeutic targets through human genetics. Nat. Rev. Drug Discov., 12, 581-594.

58. Nelson, M. R., Tipney, H., Painter, J. L., et al. (2015) The support of human genetic evidence for approved drug indications. Nat. Genet., 47, 856-860.

59. Krapohl, E., Patel, H., Newhouse, S., et al. (2018) Multi-polygenic score approach to trait prediction. Mol. Psychiatry, 23, 1368-1374.

60. Sudlow, C., Gallacher, J., Allen, N., et al. (2015) UK Biobank: An Open Access Resource for Identifying the Causes of a Wide Range of Complex Diseases of Middle and Old Age. PLoS Med., 12, 1-10.

61. Chang, C. C., Chow, C. C., Tellier, L. C. A. M., et al. (2015) Second-generation PLINK: Rising to the challenge of larger and richer datasets. Gigascience, 4, 1-16.

62. McLaren, W., Gil, L., Hunt, S. E., et al. (2016) The Ensembl Variant Effect Predictor. Genome Biol., 17, 1-14.

63. Bulik-Sullivan, B., Finucane, H. K., Anttila, V., et al. (2015) An atlas of genetic correlations across human diseases and traits. Nat. Genet, 47, 1236-1241. 
medRxiv preprint doi: https://doi.org/10.1101/2020.09.30.20204438; this version posted October 2, 2020. The copyright holder for this preprint (which was not certified by peer review) is the author/funder, who has granted medRxiv a license to display the preprint in It is made available under a CC-BY-ND 4.0 International license

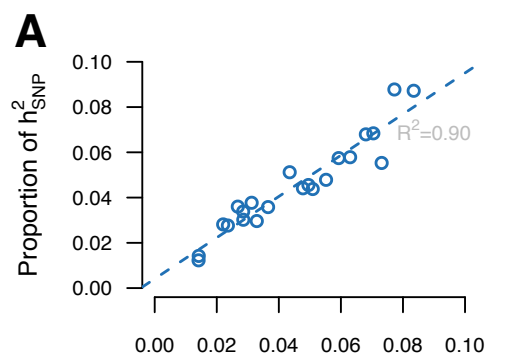

Proportion of SNPs per chromosome

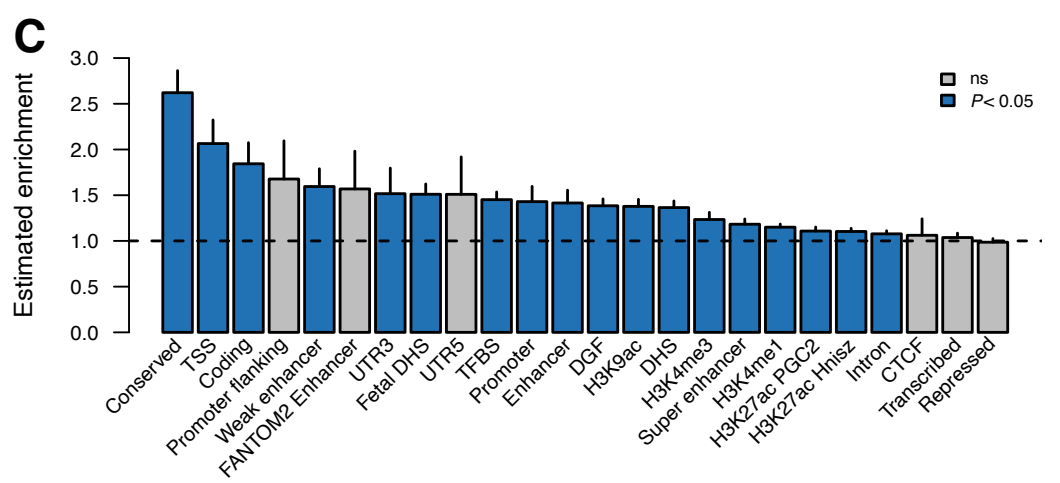

B

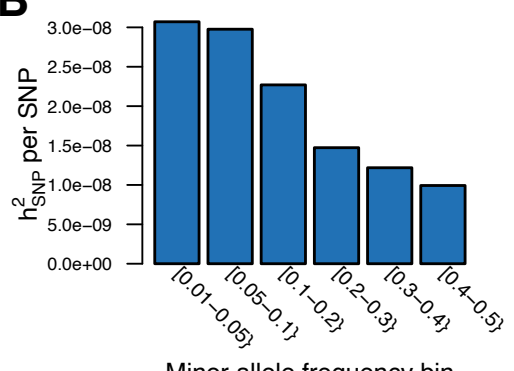

Minor allele frequency bin

$\mathrm{ns}$
$P<0.05$

Figure 2 | Partitioning of genomic variance for medication-use. A: Proportion of genomic variance captured per autosomal chromosome as function of the proportion of SNPs per chromosome. B: Proportion genomic variance, scaled by the number of SNPs, captured by minor allele frequency. C: Estimated enrichment score for functional categories. Vertical line segments mark the standard deviation on enrichment score. Horizontal dashed line marks an enrichment score of no enrichment. CTCF: a highly conserved multifunctional DNA-binding protein, DGF: digital genomic footprint, DHS: DNase I hypersensitivity sites, TFBS: transcription factor binding site, TSS: transcription start site. 
medRxiv preprint doi: https://doi.org/10.1101/2020.09.30.20204438; this version posted October 2, 2020. The copyright holder for this preprint (which was not certified by peer review) is the author/funder, who has granted medRxiv a license to display the preprint in It is made available under a CC-BY-ND 4.0 International license.

A

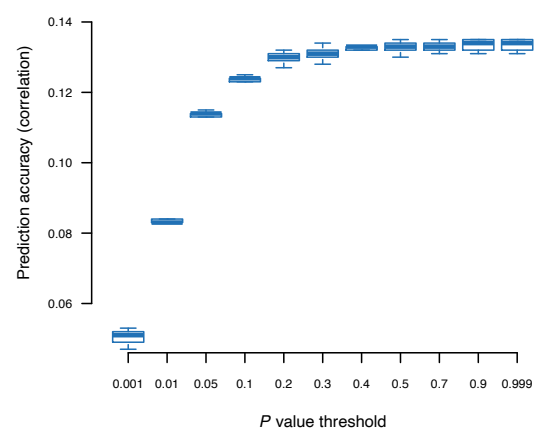

B

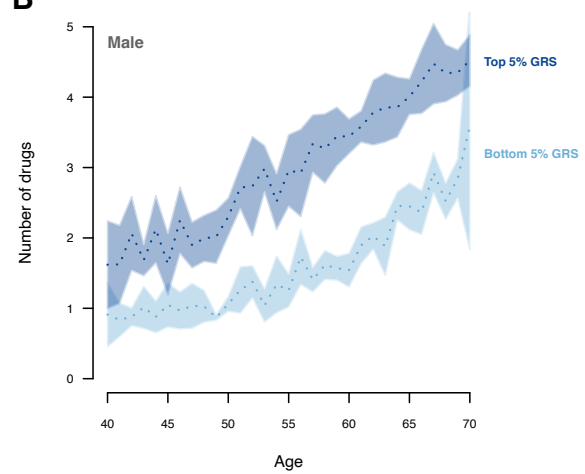

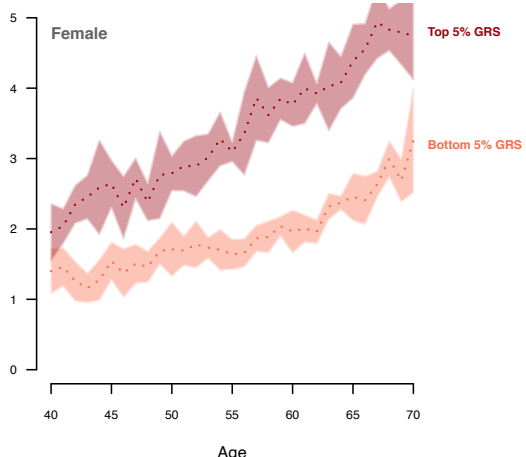

Age

Figure 3 | Prediction of number of medications used. A: Prediction accuracy (measured by the correlation between observed and predicted values) for medication-use across the range of $P$ values. Results shown is for $\mathrm{r}^{2}<0.5$ as it gave the highest accuracy across different $\mathbf{r}^{2}$-values (see Supplementary Figure $\mathrm{S} 2$ for all $\mathrm{r}^{2}$ values). B: Averaged number of drugs (over the five training sets) used by males and females stratified by top $5 \%$ and bottom $5 \%$ of genetic scores. Shadings corresponds to the standard error over the five training sets.

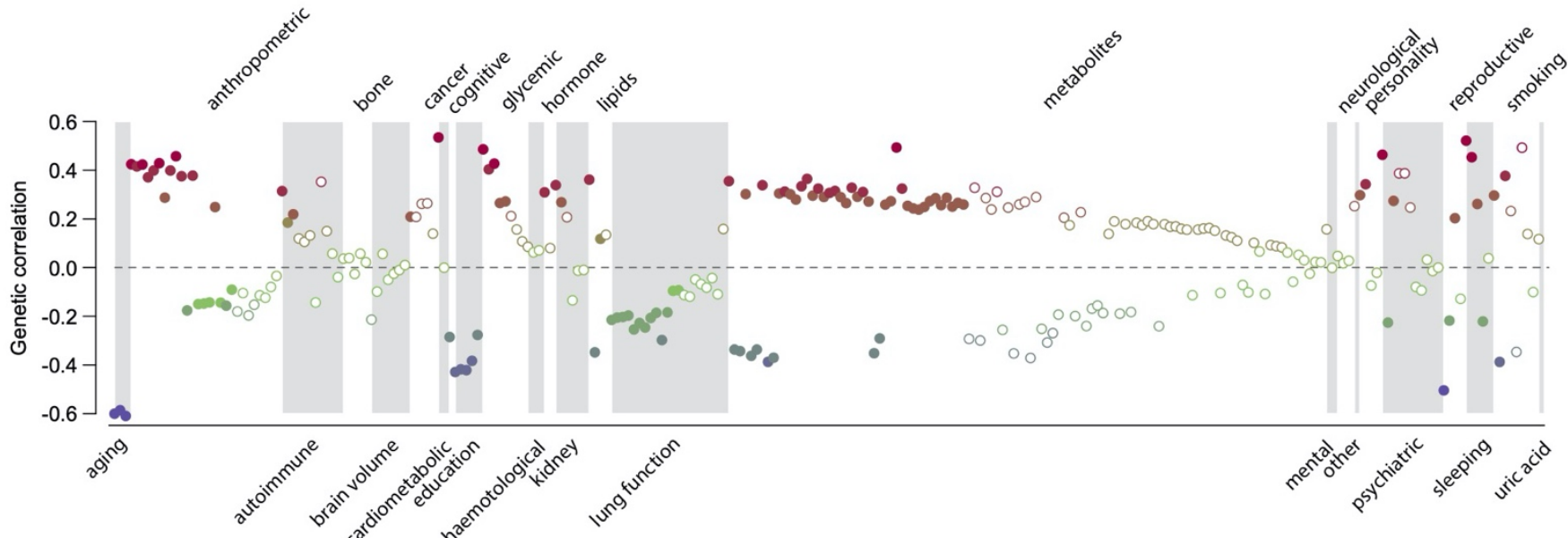

Figure 4 | Estimated genetic correlations between medication-use and 257 traits and diseases. Traits displaying significant genetic correlations are displayed as filled symbols. Details can be found in Supplementary Table S3. 
medRxiv preprint doi: https://doi.org/10.1101/2020.09.30.20204438; this version posted October 2, 2020. The copyright holder for this preprint (which was not certified by peer review) is the author/funder, who has granted medRxiv a license to display the preprint in It is made available under a CC-BY-ND 4.0 International license.

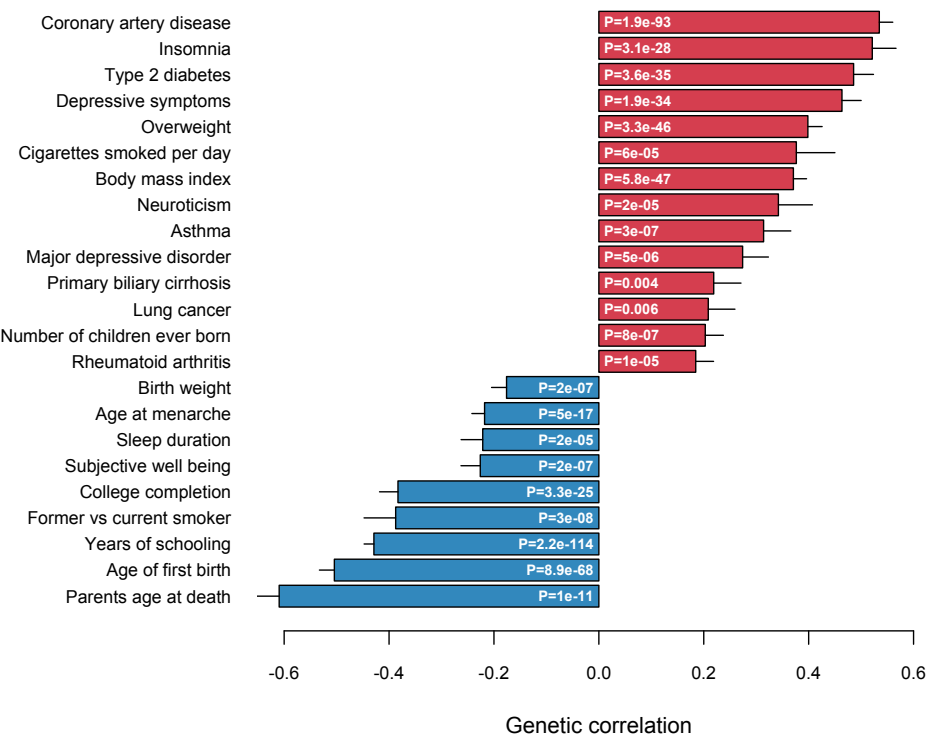

Figure 5 | Genetic correlations between medication-use and selected top categories. 